\title{
Operating Performance Analysis for Companies during GST \& SST Indirect Tax Periods, A Malaysian Evidence
}

\author{
Sitraselvi Chandren ${ }^{1, *}$, Mohd. Amir Mat Samsudin ${ }^{1}$, Sumaia Ayesh Qaderi, ${ }^{1,2}$, \\ Santhirasegaran Nadarajan ${ }^{3}$ \\ ${ }^{1}$ Tunku Puteri Intan Safinaz School of Accountancy, Universiti Utara Malaysia, Sintok, Malaysia \\ ${ }^{2}$ Department of Accounting, Hodeidah University, Hodeidah, Yemen \\ ${ }^{3}$ School of Technology Management and Logistics, Universiti Utara Malaysia, Sintok, Malaysia
}

Received December 5, 2021; Revised December 28, 2021; Accepted February 16, 2022

\section{Cite This Paper in the following Citation Styles}

(a): [1] Sitraselvi Chandren, Mohd. Amir Mat Samsudin, Sumaia Ayesh Qaderi, Santhirasegaran Nadarajan , "Operating Performance Analysis for Companies during GST \& SST Indirect Tax Periods, A Malaysian Evidence," Universal Journal of Accounting and Finance, Vol. 10, No. 2, pp. 517 - 526, 2022. DOI: 10.13189/ujaf.2022.100216.

(b): Sitraselvi Chandren, Mohd. Amir Mat Samsudin, Sumaia Ayesh Qaderi, Santhirasegaran Nadarajan (2022). Operating Performance Analysis for Companies during GST \& SST Indirect Tax Periods, A Malaysian Evidence. Universal Journal of Accounting and Finance, 10(2), 517 - 526. DOI: 10.13189/ujaf.2022.100216.

Copyright $@ 2022$ by authors, all rights reserved. Authors agree that this article remains permanently open access under the terms of the Creative Commons Attribution License 4.0 International License

\begin{abstract}
Companies require a comprehensive plan and controls to support the business operations and revenue management best practises that may influence the operating performance (profitability and liquidity position) during the Goods and Services Tax (GST) and Sales and Services Tax (SST) periods. This paper applied twosample t-test to analyse the operating performance the profitability and liquidity position for 249 listed companies from manufacturing and service sectors during the GST and SST periods. As a result, the GST has a positive impact on company profitability, whereas the SST has a slightly greater effect on the company liquidity position. In addition, the analysis on three main sectors operating performance results has similar findings with the main analysis where the profitability performance is better in the GST period while liquidity position increases in the SST period. Furthermore, the outcome of the operating performance analysis by company size reveals that small companies perform less successfully than expected for the profitability and liquidity position relative to large companies during the GST and SST periods. In spite of the fact that SST period outperforms the liquidity position for the companies; the companies still have high profitability and a manageable liquidity position during the GST era. This reveals that GST positively influences the operating performance of the companies from the perspective of effective revenue and short-term fund management. The
\end{abstract}

outcome of this study provides a novel contribution to the business leaders, authorities and academics on the effect of two indirect taxes GST and SST on the companies operating performance.

Keywords Goods and Services Tax, Liquidity, Operating Performance, Profitability, Sales and Services Tax

\section{Introduction}

On 1 September 2018, Malaysia eliminates goods and services tax (GST) and reintroduce sales and services tax (SST) after the newly formed government (Alliance of Hope) decided to switch GST to SST [1]. The GST was introduced in 2015 with purpose to increase income and reduce the country's budget deficit and replaced with SST projected to reduce living costs, particularly for the lower and middle income group [1]. This reflects that SST has positive impact to short-term fund management whereas GST possible to provide positive influence to revenue management and profitability. However, requires further investigation to validate this assumption and so far no academic journals have made the comparison between GST and SST impact particularly on operating 
performance to companies. A consumption tax is a levy on consumer purchases of goods and services that serve as a revenue source for governments [2]. The GST and the SST are consumption taxes applied on goods and services purchases [2]. The new SST, like the GST, has set a minimum amount of business turnover of RM500,000, above which the taxable firm will be subject to SST [3]. In SST the service tax of 6 per cent single levy charge by the provider of service finally [2]. The GST is charged on the value-added to goods or services for each separate processor in the manufacturing and distribution chain [4]. This raised questions on how the taxable manufacturer or service sectors managed the business processes during the implementation of GST or SST. Further, does the implementation of GST and SST influence the operating performance of the companies?

In GST system the ultimate tax burden falls on consumers [4]. This creates a necessity to investigate whether the reintroduction to SST from GST has any implication to the companies operating performance. [5] study the operating performance during GST implementation in Malaysia report decrease in operating performance during GST implementation and recover the operating performance one year after the implementation period. This indicates that the consumption tax implementation influences the operating performance of business which requires a proper business policy and procedures to cope with the implementation of the consumption tax. The operating performance reflects on stability and position of firms from the well managed sales, expenses, and effective working capital on strong liquidity position including sound cash flow [5]. The good record of operating benefits all stakeholders of the firm [6]. Thus, a sound and sustainable operating performance is essential for company prospect of growth and for the benefits of entire stakeholders. From the investigation of the impact of GST and SST implementation on operating performance will provide evidence on how the indirect or consumption tax impacted the firms particularly on its performance and position. To our best knowledge no studies conducted to compare the operating performance analysis representing profitability and liquidity position of companies during GST and SST periods. The results of this paper consequently will report the following contributions. Firstly, the outcome reports on the operating performance mainly the profitability and liquidity position of the companies in manufacturing and service sectors during GST and SST indirect or consumption tax periods. The results will provide evidence which indirect tax (GST or SST) periods are healthy for the companies. Secondly, the comparison of operating performance analysis for large and small companies during GST and SST periods to determine how the large and small companies manage their revenue, profitability and liquidity position during the indirect tax periods. Thirdly, the operating performance analysis for the three main sector companies during the
GST and SST periods shall validate the first operating performance analysis outcome comparing the two indirect tax periods. Further, the objective of the analysis is to determine the operating performance for each three main sectors and also to validate whether the overall findings are consistent with each main three sectors finding during the two indirect tax periods. Thus, the investigation of two indirect tax periods will provide a framework of analysis for the operating performance management of the companies on adopting and managing their business operation during the implementation and transition of the indirect tax from GST to SST. This information is necessary for the regulators on the degree of the extent the consumption taxes have effects on the operating performance of the companies during the implementation of the GST and SST.

The paper is organised in the following ways after the introduction section. Section 2 represents the literature review and Section 3 is the methodology for this paper. The results are discussed in Section 4 and the summary of the study in Section 5.

\section{Literature Reviews}

\subsection{Consumption Taxes Transition}

The transition from GST to SST is a tax reform program strategy by the government to increase the Malaysian taxation system effectiveness and efficiency [7]. The major goal of establishing GST initially was to increase government revenue as the SST system considered opaque [8]. Thus, the GST will also have a positive impact to companies' revenue and profitability. [9] report that GST is a "regressive tax", implementation may influence the Malaysia household. The producer is able to claim back the GST paid from government, however, the producer may transfer the cost directly to the purchaser (consumer) with reason to sustain its own capital turnover due to complex and time consuming process, finally the consumer confronts with double taxation cost from the producer and their own tax cost [7]. Further, the tax refund system is possible to give opportunity for corruption and ethical issues in business by exploiting the system weakness [7]. Nevertheless GST believes to provide positive impact to income and future economy, the implementation of GST may influence the cash flow management and price setting for goods or services [10]. The [5] study agrees with the [10] statement that GST implementation influences the cash flow and firm pricing policy, thus, requires good support, knowledge and expertise in management and all department staffs for the indirect tax implementation. [11] identify that the consumer products sector of the Malaysian listed firms have lower corporate performance and shareholders' equity after GST implementation, thus, listed firms are afflicted due to GST compared to other 
indirect tax.

The standard rate for SST 2.0 is at $5 \%$ to $10 \%$ on goods sold and $6 \%$ on services [12] whereas GST is at $6 \%$ at every level of sales [13]. Despite the fact that GST implementation in the Malaysian tax system appears to have a negative impact on the welfare of B40 and M40 households when compared to the SST, the impacts are "totally different", further in GST characteristics the high income groups spend higher on tax relative to targeted income groups [13]. Based on 124 economic sectors, the result of Input-Output price modelling document that the SST reintroduction in contrast to GST rise of the cost of production for each large economic sector [14]. The reintroduced SST will erode from the cost-of-production increase, as commodity prices are anticipated to rise [14]. This creates important issues to identify whether the transition of GST to SST influences the companies operating performance measured by profitability and liquidity position.

\subsection{Operating Performance}

The industry portfolio of companies is significant for explaining their profit performance [15]. Various studies investigated different variables possible to influence company performance for business success or survival or business which mainly depends on the company profitability [16]. It is essential to improve company performance with suitable "strategies, techniques and business tools" created as it is the barometer of the company success regarded as benchmark to invest funds by the investors [17]. The financial statement analysis is a business analysis that establishes the firm performance and position [18]. In fact, the financial statements provide different measurements e.g. "net income (NI), return on assets (ROA) or return on equity (ROE)" to measure the firm performance [17]. The financial statement analysis is important for the firms and stakeholders. The profitability ratios are regularly used method for financial analysis key measures for overall efficiency and performance of companies [16]. The operating performance is one of the financial statement analyses that reflect on the profitability and liquidity position effectiveness and efficiency [5]. In addition, the investors will react positively signalling the fund invested that increases stock market prices of the company [17]. The shareholder wealth is protected once firm has good governance and positive operating performance [19]. For operating performance, profitability reflects on revenue for being able to cover the cost and liquidity position highlights the company abilities to meet the short-term liabilities or commitments [5]. Further, company performance improves with stern tax enforcement [20]. [5] study analyse the operating performance represented by profitability and liquidity during the GST implementation period. Indeed, this study adopts different approaches from [5] study by comparing the operating performance (profitability and liquidity) during GST and SST periods.

\section{Methodology}

For operating performance analysis for the GST and SST tax periods the data was hand collected from the Bursa Malaysia for the 258 Malaysia listed firms from year 2015 to 2019. The listed firms consist of manufacturing and service sectors in accordance to SST indirect tax in Malaysia with financial year ended as at 30 September or 31 October or 30 November or 31 December after the SST implementation date on 1 September 2018. Due to incomplete information, 9 firms with missing data were also excluded from the study. The selected sample firms detail as follows: 83 firms are from consumer product and services, 105 firms from industrial product and services, 24 firms from telecommunications and media, 13 firms from transportation and logistics, 17 firms from technology and 7 firms from utility. Thus, we used total 249 sample firms for this study.

The two-sample t-test was employed to analyse the mean comparison of the profitability and liquidity position for the GST and SST indirect tax periods. The t-test is used to see if there is a significant difference between the means of two groups [21]. Two-sample t-test compares the means of two groups (GST n SST) under the assumption that both samples are random, independent, and normally distributed with unknown but equal variances. The operating analysis is conducted in three sections, first use two-sample t-test to compare the mean difference for the overall operating performance during the GST (2015 and 2016) and SST (2018 and 2019) periods. Secondly the operating performance mean difference is carried out to analyse the performance of large and small firms during the GST (2015 and 2016) and SST (2018 and 2019) periods using the two-sample t-test. Thirdly, three main sectors from consumer product and services, industrial product and services and telecommunications and media operating performance were analysed for GST (2015 and 2016) and SST (2018 and 2019) periods using the two-sample t-test. The three sectors representing 33 percent from consumer product and services, 45 percent from industrial product and services and 10 percent from telecommunications and media with total of 88 percent from the overall 249 sample companies would be significant to generalize the outcome of the findings on the operating performance analysis during the GST and SST periods.

The operating performance analysis is classified into two main sections namely the profitability (OPP) and liquidity position (OPL). For OPP represented by sales growth (SG), operating profit margin (OPM), earnings per share (EPS), return on asset (ROA) and inventory turnover (IT). The OPL represented by operating cash flow ratio (OCR), current ratio (CR), cash ratio (CashR) and debt ratio (DR). Table 1 presents the measurements of 
the financial ratios of the OPP and OPL variables.

\section{Results}

\subsection{Descriptive Statistics}

The Table 2 Panel A presents the descriptive statistics representing mean, standard deviation, median, minimum and maximum for the operating performance variables represent profitability and liquidity for both GST and SST periods. Table 3 also presents separately the descriptive analysis results for GST period in Panel B and SST period in Panel C. Detail discussion for the mean difference for the operating performance variables for GST and SST periods will be discussed in the findings of the t-test results in Table3.

Table 1. The Variables Measurements

\begin{tabular}{|c|l|l|}
\hline OPP & Operating Performance- Profitability \\
\hline SG & Sales growth & Ratio change in sales from the year t to year t-1 \\
\hline OPM & Operating profit margin & Ratio of net profit divided by revenue \\
\hline EPS & Earnings per share & Net income divided by weighted average of common shares outstanding \\
\hline ROA & Return on asset & Ratio of net income divided by total assets \\
\hline IT & Inventory turnover & Cost of goods sold divided by average inventory [Beginning +Ending Inventory/2] \\
\hline OPL & Operating Performance- Liquidity \\
\hline OCR & Operating cash flow ratio & Ratio of net cash flow from operating activities divided by total assets \\
\hline CR & Current ratio & Current assets divided by current liabilities \\
\hline Cash & Cash ratio & Ratio of cash deposit to current liabilities \\
\hline DR & Debt ratio & Total liabilities divided by total assets \\
\hline
\end{tabular}

Table 2. Variables Descriptive Statistics

\begin{tabular}{|c|c|c|c|c|c|}
\hline \multicolumn{6}{|c|}{ Panel A: Variables Descriptive Statistics for Combined GST and SST $(2015,2016,2018$ n 2019) $(\mathrm{N}=996)$} \\
\hline Variables & Mean & Std. Dev. & Median & Min & Max \\
\hline SG & 0.058 & 0.574 & 0.016 & -0.995 & 12.638 \\
\hline OPM & 0.195 & 6.819 & 0.040 & -10.324 & 214.243 \\
\hline EPS & 0.116 & 0.488 & 0.050 & -6.000 & 8.070 \\
\hline ROA & 0.039 & 0.286 & 0.038 & -3.868 & 4.910 \\
\hline IT & 28.605 & 148.423 & 4.613 & -0.038 & 2011.386 \\
\hline OCR & 0.362 & 1.255 & 0.234 & -10.843 & 10.728 \\
\hline CR & 1.149 & 13.433 & 0.506 & 0.007 & 418.600 \\
\hline CashR & 1.241 & 3.565 & 0.440 & 0.001 & 62.600 \\
\hline DR & 0.386 & 0.446 & 0.343 & 0.004 & 12.595 \\
\hline \multicolumn{6}{|c|}{ Panel B: Variables Descriptive Statistics for GST Period (2015 and 2016) $(\mathrm{N}=498)$} \\
\hline Variables & Mean & Std. Dev. & Median & Min & Max \\
\hline SG & 0.034 & 0.195 & 0.029 & 0.416 & 0.549 \\
\hline OPM & 0.041 & 0.181 & 0.049 & -0.691 & 0.355 \\
\hline EPS & 0.114 & 0.218 & 0.058 & -0.289 & 0.879 \\
\hline ROA & 0.050 & 0.085 & 0.046 & -0.168 & 0.272 \\
\hline IT & 15.025 & 32.620 & 4.901 & 0.000 & 166.031 \\
\hline OCR & 0.389 & 0.620 & 0.237 & -0.812 & 2.261 \\
\hline CR & 0.610 & 0.448 & 0.500 & 0.075 & 2.154 \\
\hline CashR & 0.936 & 1.345 & 0.463 & 0.021 & 6.390 \\
\hline DR & 0.365 & 0.197 & 0.337 & 0.057 & 0.832 \\
\hline \multicolumn{6}{|c|}{ Panel C: Variables Descriptive Statistics for SST Period (2018 and 2019) (N= 498) } \\
\hline Variables & Mean & Std. Dev. & Median & Min & Max \\
\hline SG & 0.007 & 0.193 & 0.011 & 0.416 & 0.549 \\
\hline OPM & 0.005 & 0.198 & 0.030 & -0.691 & 0.355 \\
\hline EPS & 0.084 & 0.220 & 0.039 & -0.289 & 0.879 \\
\hline ROA & 0.032 & 0.086 & 0.029 & -0.168 & 0.272 \\
\hline IT & 13.259 & 29.535 & 4.401 & 0.000 & 166.031 \\
\hline OCR & 0.344 & 0.573 & 0.230 & -0.812 & 2.261 \\
\hline CR & 0.636 & 0.482 & 0.511 & 0.075 & 2.154 \\
\hline CashR & 0.998 & 1.506 & 0.388 & 0.021 & 6.390 \\
\hline DR & 0.375 & 0.206 & 0.354 & 0.057 & 0.832 \\
\hline
\end{tabular}


Table 3. The Operating Performance during GST and SST

\begin{tabular}{|c|c|c|c|c|c|c|}
\hline \multirow{2}{*}{ Variable } & GST & SST & \multirow{2}{*}{ Diff } & \multirow{2}{*}{ St Err } & \multirow{2}{*}{ t-value } & \multirow{2}{*}{ p-value } \\
\hline & Mean Value & Mean Value & & & & \\
\hline \multicolumn{7}{|l|}{ OPP } \\
\hline SG & 0.034 & 0.007 & 0.0270 & 0.0123 & 2.1999 & $0.0280 * *$ \\
\hline OPM & 0.041 & 0.005 & 0.0362 & 0.0120 & 3.0108 & $0.0027^{* * *}$ \\
\hline EPS & 0.114 & 0.084 & 0.0300 & 0.0139 & 2.1624 & $0.0308 * *$ \\
\hline ROA & 0.050 & 0.032 & 0.0173 & 0.0054 & 3.1955 & $0.0014 * * *$ \\
\hline IT & 15.025 & 13.259 & 1.7664 & 1.9719 & 0.8958 & 0.3706 \\
\hline \multicolumn{7}{|l|}{ OPL } \\
\hline OCR & 0.389 & 0.344 & 0.0454 & 0.0378 & 1.1991 & 0.2308 \\
\hline CR & 0.610 & 0.636 & -0.0264 & 0.0295 & -0.8964 & 0.3702 \\
\hline CashR & 0.936 & 0.998 & -0.0620 & 0.0904 & -0.6848 & 0.4936 \\
\hline DR & 0.365 & 0.375 & -0.0102 & 0.0128 & -0.7993 & 0.4243 \\
\hline
\end{tabular}

\subsection{Two- Sample T-Test Results}

Table 3 presents the two-sample t-test results for the GST period (2015 to 2016) and SST period (2018 to 2019). The purpose of this test is to compare operating performance during and after GST period with SST period. The sales growth (SG) mean in GST period (0.034) is greater than SST period (0.007) with a 5 percent significant level. The finding is consistent with [5] study that the firm shows improvement in sales growth due to effective pricing setting policy one year after GST implementation period. Thus, companies' revenue management is better in GST period relative to SST period. GST period OPM mean (0.041) is higher than SST period mean (0.005) with significant mean difference at 1 percent. The operating profit that reflects the income from operating activities [18] indicates company operating profit better during GST period. The EPS shows significant mean difference $(p<.05)$ where the SST period mean (0.084) 36 percent lower than GST period mean (0.114). The earnings per share reflect the income amount earned from the outstanding shares [22], thus, the GST period has outperformed the SST period for the EPS performance. The return on assets (ROA) reports the management's success in turning a profit with the company's assets [23]. The GST period ROA mean (0.050) larger than SST period mean (0.032) at 1 percent significant level mean difference. The inventory turnover is indication of inventory management efficiency [24]. The inventory turnover (IT) mean for GST period (15.025) relatively more than SST period (13.259) by 13 percent. This indicates that during GST period firm has good track of sales record and effective inventory cycle time. In sum, the better profitability results during GST period indicate that companies have increase in the sales trend, business operations are efficient and more profits are earned from the revenue management including effective inventory cycle time. Consistently, the outcome supports that the GST increases the revenue [8] and possible to provide pragmatic consequences to income and future economy, despite its possible effect to cash flow management and price setting [10]. Further, with a more transparent process, GST increases the tax revenue [25]. Thus, the results reveal that GST period has positive impact to firm profitability performance from the efficacious pricing policy and revenue management.

The operating cash flow ratio (OCR) describes the firm's ability to meet its maturing obligations in terms of liquidity [18]. The OCR opines a marginal increase mean results for GST period (0.389) compared to SST period (0.344). In addition, high OCR indicates that a corporation has generated more cash than required to pay down its current liabilities in a given period. GST has good profitability position which would able to meet its operating activities short-term commitments; this positively correlates with the OCR outcome. However, the current ratio (CR) mean for SST period (0.636) is slightly higher than GST period (0.610). The current asset-to-current-liability ratio examines if current assets (cash or assets projected to be turned into cash within a year) are sufficient to cover current obligations (those obligation) [23]. This indicates that during SST period the company is in a better position and with good financial health to meet its obligations. Similarly the cash ratio (CashR) shows to some extent higher reading for SST period (mean: 0.998) compared to GST period (mean: 0.936). CashR reports on the available cash to meet current commitments [18]. Cash is the most liquid asset, allowing companies to be more proactive in their financial decisions and decrease solvency concerns [26]. The firms in SST period are able to pay back short-term debt with cash and cash equivalents. The debt ratio (DR) is a metric for determining operating leverage [23]. The GST and SST periods debt ratio (DR) consistently around 30 
percent demonstrates that debts levels for both periods are lesser than the assets where the companies are able to meets its obligations. The SST period DR (0.375) is insignificantly greater than 0.365 the GST period. The overall OPL results reveal insignificant mean difference for GST and SST periods as the liquidity variable ratios outcome between GST and SST are almost similar. However, the SST period in general has slightly acceptable short-term liquidity position relative to GST period.

\subsection{Two-Sample T-Test by Company Size Large $n$ Small-Overall Companies}

The Table 4 presents the operating performance mean differences by company size for GST period and followed by Table 5 reports the operating performance mean differences by company size for SST period. The company size for the GST and SST periods is measured by the total assets of the companies. For the both GST and SST periods the operating performance for profitability and liquidity (OPP: OPM, EPS, ROA, IT; OPL: CR, CashR, DR) consistently reports significant mean differences among the small and large companies except for SG (OPP) and OCR (OPL) for GST and SST periods including IT for SST period. During the GST period in Table 4, the large companies have reported greater OPM (Mean: 0.0704), EPS (Mean:, 0.1967), ROA (Mean: 0.6092), IT (Mean: 19.3798), CR (Mean: 0.7289) and DR (Mean: 0.4173) relative to small companies at significant mean difference $(\mathrm{p}<.01)$ except for the CashR (Mean: 0.7170 ) reports lower than small companies. Similarly, during the SST period in Table 5, OPM (Mean: 0.0410), EPS (Mean: 0.1463), ROA (Mean: 0.0460), CR (Mean: 0.7229 ) and DR (Mean: 0.4208) in large companies are higher than small companies at significant mean difference $(\mathrm{p}<.01)$ except for the CashR (Mean: 0.6991) reports lower than small companies. Thus, large companies consistently have good track of operating performance during GST and SST periods.

Overall the outcome opines that the large companies have good operating policy and procedures to accommodate the implementation and development for GST and SST in their companies without jeopardizing the profitability and liquidity position of the operating performance. Basically, the large and small including medium size companies have distinct resources and capabilities [27]. Larger companies benefit from economies of scale and scope and make greater use of financial and human resources as a result of their size, resulting in higher profitability than small companies [28]. Indeed, existence of positive associations between firm performances with company sizes [29]. The micro, small and medium companies face constricting obstacles that opportunistically restrict their capacities, preventing them from taking use of the advantageous chances available, notably in the aspect of financial [30]. The small companies require promoting good revenue management and effective business operations to accommodate the GST and SST indirect tax system implementation.

Table 4. The Operating Performance by Company Size for GST Period

\begin{tabular}{|c|c|c|c|c|c|}
\hline \multirow{2}{*}{ Variable } & $\begin{array}{c}\text { Companies with small size } \\
\text { (N:267) }\end{array}$ & $\begin{array}{c}\text { Companies with large size } \\
\text { (N:231) }\end{array}$ & \multicolumn{2}{|c|}{ T-test } \\
\cline { 2 - 6 } & Mean & Mean & Mean difference & t-value & p-value \\
\hline OPP & & & & & 0.8297 \\
\hline SG & 0.0406 & 0.0261 & -0.0540 & -3.3462 & $0.0009^{* * *}$ \\
\hline OPM & 0.0164 & 0.0704 & -0.1546 & -8.4132 & $0.0000^{* * *}$ \\
\hline EPS & 0.0421 & 0.1967 & -0.0212 & -2.7948 & $0.0054^{* * *}$ \\
\hline ROA & 0.0397 & 0.6092 & -8.1219 & -2.7898 & $0.0055^{* * *}$ \\
\hline IT & 11.2579 & 19.3798 & & & \\
\hline OPL & & & -0.0079 & -0.1421 & 0.8871 \\
\hline OCR & 0.3857 & 0.3937 & -0.2226 & -5.6960 & $0.0000^{* * *}$ \\
\hline CR & -0.5063 & 0.7289 & 0.4088 & 3.4193 & $0.0007^{* * *}$ \\
\hline CashR & 1.1258 & 0.7170 & -0.0985 & -5.7360 & $0.0000^{* * *}$ \\
\hline DR & 0.3189 & 0.4173 & & \\
\hline Note: $* * *$ Significance at the $1 \%$ level, ** Significance at the $5 \%$ level, * Significance at the $10 \%$ level & \\
\hline
\end{tabular}


Table 5. Operating Performance by Company Size for SST Period

\begin{tabular}{|c|c|c|c|c|c|}
\hline \multirow{2}{*}{ Variable } & \multirow{2}{*}{$\begin{array}{c}\begin{array}{c}\text { Companies with small size } \\
\text { (N:231) }\end{array} \\
\text { Mean } \\
\end{array}$} & \multirow{2}{*}{$\begin{array}{c}\begin{array}{c}\text { Companies with large size } \\
\text { (N:267) }\end{array} \\
\text { Mean } \\
\end{array}$} & \multicolumn{3}{|c|}{ T-test } \\
\hline & & & Mean difference & t-value & p-value \\
\hline \multicolumn{6}{|l|}{ OPP } \\
\hline SG & -0.005 & 0.0170 & -0.0220 & -1.2718 & 0.2040 \\
\hline OPM & -0.0360 & 0.0410 & -0.0770 & -4.4148 & $0.0000^{* * *}$ \\
\hline EPS & 0.0114 & 0.1463 & 0.0838 & -7.1644 & $0.0000^{* * *}$ \\
\hline ROA & 0.0163 & 0.0460 & -0.0296 & -3.8967 & $0.0001^{* * *}$ \\
\hline IT & 12.1689 & 14.2018 & -2.0329 & -0.7657 & 0.4442 \\
\hline \multicolumn{6}{|l|}{ OPL } \\
\hline OCR & 0.3011 & 0.3812 & -0.0800 & -1.555 & 0.1205 \\
\hline CR & 0.5356 & 0.7229 & -0.1873 & -4.4069 & $0.0000^{* * *}$ \\
\hline CashR & 1.1343 & 0.6991 & 0.6446 & 4.8721 & $0.0000^{* * *}$ \\
\hline DR & 0.3216 & 0.4208 & -0.0991 & -5.5168 & $0.0000^{* * *}$ \\
\hline
\end{tabular}

\subsection{Two-Sample T-Test Result by Three Main Sectors}

Additional analysis is conducted to observe separately for the three main sectors from the sample size: consumer product and services (83 companies), industrial product and services (105 companies) and telecommunications and media (24 companies), operating performance representing profitability and liquidity position during the GST and SST periods. The reason for the additional analysis is to validate the main findings outcome in Table 3. Table 6 presents the operating performance for 332 sample observations from consumer product and services sector. The outcome reveals that companies in consumer product and services sector have greater profitability performance (OPP) during GST period relative to SST period (mean difference: SG:0.0300, OPM:0.0322, EPS:0.0033, ROA:0.0110, IT:1.92) even with significant mean difference at 10 percent level reported for OPM only. Conversely, the companies have slightly better liquidity position (OPM) in SST period compared to GST period with insignificant mean difference for OCR (0.0095), CR(0.0012), CashR (0.0948) and (0.0080). The outcome in Table 6 is almost similar to Table 3 where overall companies including the companies from consumer product and services sector perform better in profitability in GST and liquidity position in SST period. Despite [11] report that consumer products sector faces decreased corporate performance, this study finds that the consumer product and services sector perform better in GST period relative to SST period.
Table 7 discloses the operating performance analysis results for the 105 firms from industrial product and services sectors during GST and SST periods. The results report profitability is higher for GST period with OPP mean difference for SG is 0.0070 , OPM is 0.0365 , EPS is 0.0521 , ROA is 0.0220 and IT is 0.0657 ( $\mathrm{p}<.01$ for EPS including ROA and $\mathrm{p}<.05$ for OPM). As for OPL, the SST liquidity positions are consistently better disregarding with the insignificant mean difference for CR of 0.0002, CashR of 0.0148 and DR of 0.0096 except for OCR mean difference of $0.1153(\mathrm{p}<.05)$ lower in SST period. Generally, the outcome of the results are relatively similar to Table 6 and Table 7, comparing the two indirect tax-period operating performance the GST period shows good profitability performance (OPP) and SST period records moderately enhance liquidity position.

Table 8 reports the operating performance for 24 companies from telecommunications and media sector during the GST and SST periods. The SG records positive mean difference of $0.1191(\mathrm{p}<.05)$ followed by the insignificant mean difference for EPS of 0.0021 and ROA of 0.0075 where validates the fact that GST period profitability higher than the SST period. The SST period liquidity position is marginally better than the GST period based on OCR and CashR insignificant mean difference of 0.0115 and 0.4599 . The findings from Table 6, 7 and 8 validate the main results operating performance analysis in Table 3 that GST has positive repercussion to profitability performance, SST has acceptable impact to the liquidity position of the companies. 
Table 6. Operating Performance for Consumer Product and Services Sector

\begin{tabular}{|c|c|c|c|c|c|c|}
\hline \multirow{2}{*}{ Variable } & GST & SST & \multirow{2}{*}{ Diff } & \multirow{2}{*}{ St Err } & \multirow{2}{*}{ t-value } & \multirow{2}{*}{ p-value } \\
\hline & Mean Value & Mean Value & & & & \\
\hline \multicolumn{7}{|l|}{ OPP } \\
\hline SG & 0.0422 & 0.0123 & 0.0300 & 0.0190 & 1.5789 & 0.1153 \\
\hline OPM & 0.0203 & -0.0119 & 0.0322 & 0.0194 & 1.6626 & $0.0974 *$ \\
\hline EPS & 0.1433 & 0.1400 & 0.0033 & 0.0307 & 0.1072 & 0.9147 \\
\hline ROA & 0.0514 & 0.0404 & 0.0110 & 0.0100 & 1.0912 & 0.2760 \\
\hline IT & 17.2931 & 15.3730 & 1.9200 & 3.7484 & 0.5122 & 0.6088 \\
\hline \multicolumn{7}{|l|}{ OPL } \\
\hline OCR & 0.3040 & 0.3136 & -0.0095 & 0.0578 & -0.1651 & 0.8689 \\
\hline CR & 0.6954 & 0.6966 & -0.0012 & 0.0528 & -0.0237 & 0.9811 \\
\hline CashR & 0.7758 & 0.8706 & -0.0948 & 0.1454 & -0.6517 & 0.5151 \\
\hline DR & 0.3988 & 0.4068 & -0.0080 & 0.0230 & -0.3474 & 0.7285 \\
\hline
\end{tabular}

Table 7. Operating Performance for Industrial Product and Services Sector

\begin{tabular}{|c|c|c|c|c|c|c|}
\hline \multirow{2}{*}{ Variable } & GST & SST & \multirow{2}{*}{ Diff } & \multirow{2}{*}{ St Err } & \multirow{2}{*}{ t-value } & \multirow{2}{*}{ p-value } \\
\hline & Mean Value & Mean Value & & & & \\
\hline \multicolumn{7}{|l|}{ OPP } \\
\hline SG & 0.0183 & 0.0113 & 0.0070 & 0.0185 & 0.3805 & 0.7038 \\
\hline OPM & 0.0460 & 0.0096 & 0.0365 & 0.0153 & 2.3914 & $0.0172 * *$ \\
\hline EPS & 0.0938 & 0.0416 & 0.0521 & 0.0151 & 3.4429 & $0.0060^{* * *}$ \\
\hline ROA & 0.0468 & 0.0246 & 0.0220 & 0.0069 & 3.2017 & $0.0015^{* * *}$ \\
\hline IT & 7.3436 & 7.2780 & 0.0657 & 1.8002 & 0.0365 & 0.9709 \\
\hline \multicolumn{7}{|l|}{ OPL } \\
\hline OCR & 0.4040 & 0.2886 & 0.1153 & 0.0580 & 1.9874 & $0.0475 * *$ \\
\hline CR & 0.5469 & 0.5471 & -0.0002 & 0.0396 & -0.0051 & 0.9960 \\
\hline CashR & 1.0029 & 1.0178 & -0.0148 & 0.1525 & -0.0973 & 0.9225 \\
\hline DR & 0.3266 & 0.3361 & -0.0096 & 0.0177 & -0.5412 & 0.5887 \\
\hline
\end{tabular}

Table 8. Operating Performance for Telecommunications and Media Sector

\begin{tabular}{|c|c|c|c|c|c|c|}
\hline \multirow{2}{*}{ Variable } & GST & SST & \multirow{2}{*}{ Diff } & \multirow{2}{*}{ St Err } & \multirow{2}{*}{ t-value } & \multirow{2}{*}{ p-value } \\
\hline & Mean Value & Mean Value & & & & \\
\hline \multicolumn{7}{|l|}{ OPP } \\
\hline SG & 0.1095 & -0.0096 & 0.1191 & 0.0495 & 2.4043 & $0.0182^{* *}$ \\
\hline OPM & 0.0970 & 0.0988 & -0.0019 & 0.0312 & -0.0594 & 0.9528 \\
\hline EPS & 0.0430 & 0.0409 & 0.0021 & 0.0189 & 0.1101 & 0.9125 \\
\hline ROA & 0.0795 & 0.0720 & 0.0075 & 0.0201 & 0.3742 & 0.7091 \\
\hline IT & 21.0251 & 24.5683 & -3.5432 & 8.8134 & -0.4020 & 0.6886 \\
\hline \multicolumn{7}{|l|}{ OPL } \\
\hline OCR & 0.5569 & 0.5684 & -0.0115 & 0.1380 & -0.0836 & 0.9336 \\
\hline CR & 0.3977 & 0.3752 & 0.0226 & 0.0415 & 0.5435 & 0.5881 \\
\hline CashR & 1.1620 & 1.6218 & -0.4599 & 0.2800 & -1.6426 & 0.1038 \\
\hline DR & 0.3162 & 0.2926 & 0.0237 & 0.0367 & 0.6452 & 0.5204 \\
\hline
\end{tabular}




\section{Conclusions}

The companies require maintaining healthy operating performance from the effective business operation and efficient revenue including fund management (short and long-term) for sustainable companies' development that contributes indirectly to country economic growth. This is the companies' culture and practices to maximize the shareholders' wealth together with building the trust of confidence to entire stakeholders. In Malaysia, the GST was implemented in year 2015 and subsequently undertaken a transition to SST in year 2018. The implementation of GST and SST requires companies to have a proper plan and procedures to support the business operations best practices as to mitigate any losses that possible to affect the operating performance in terms of profitability and liquidity position. The objective of this paper is to analyze the operating performance (profitability and liquidity position) of the 249 companies for the GST period (2015 to 2016) in comparison to SST period (2018 to 2019)

From the findings, we discover that the company's profitability is higher during the GST period compared to the SST period. Conversely, the liquidity position of the companies is marginally better during the SST period relative to GST period. The outcome contributes that GST has positive effect to companies' profitability while SST is healthy to companies' liquidity position. This could be one of the possible reasons to transit from GST to SST as to improve the fund or short-term cash flow management which is shown as an evidence on the marginal improvement of companies' liquidity position during SST. The additional analysis on the three main sectors namely from consumer product and services, industrial product and services and telecommunications and media operating performance analysis reports the similar outcome that profitability performance better in GST period and liquidity position better in SST period. Even the SST period marginally outperforms the liquidity position for the companies, practically, the companies have good profitability performance and acceptable liquidity position during GST period. The outcome supports the fact stated in [5] study that GST is business friendly indirect tax to companies. Furthermore, the SST is more likely to have repercussion on cash flow and liquidity position rather on profitability and revenue performance for corporate companies. In addition, the operating performance analysis by company size shows that large companies have superior operating performance relative to small companies during GST and SST periods. Thus, the small companies require developing an effective business operation, cash flow policy and efficient revenue management including a better pricing policy for a positive operating performance (profitability and liquidity). The implication of this study highlights the importance of managing operating performance (profitability and liquidity) for the company growth and stability during the GST and SST periods. The limitation of this paper only examines six main sectors to analyse the operating performance during the GST and SST periods. For future studies recommend to analyse the operating performance with more sectors from the listed companies.

\section{Acknowledgements}

This research was supported by Ministry of Higher Education (MOHE) of Malaysia through Fundamental Grant Scheme for Research Acculturation of Early Career Researchers (RACER/1/2019/SS01/UUM//6).

\section{REFERENCES}

[1] Kasipillai, J., "Malaysia: The prospects and drawbacks of navigating from GST to SST,” Tax Specialist, vol. 22, no.1, pp.40-42, 2018. Doi/abs/10.3316/informit.3484422673449 26

[2] Ahmad, M., Elatrash, R. J., Lukman, B., " Shariah view on consumption tax: Malaysian GST and SST as case studies,” Malaysian Journal of Consumer and Family Economic, vol. 22, pp.28-41, 2019. https://www.majcafe.com/wp-content

[3] Royal Malaysian Customs Department. Retrieved from Official Website of Royal Malaysian Customs Department, 2018. https://mysst.customs.gov.my/

[4] Palil, M. R., Ibrahim, M., "The impacts of goods and services tax (GST) on middle income earners in Malaysia," World Review of Business Research, vol. 1, no.3, pp.192-206, 2011.

[5] Chandren, S., Che Ahmad, A., Nadarajan, S,. "Operating performance analysis and Goods Service Tax implementation in Malaysia," International Journal of Supply Chain Management, vol. 7, no.3, pp.38-41, 2018. https://www.researchgate.net/profile

[6] Chandren, S., Qaderi, S. A., Ghaleb, B. A. A., "The influence of the chairman and CEO effectiveness on operating performance: Evidence from Malaysia,” Cogent Business \& Management, vol.8, no.1, 1935189, 2021. Doi.org/10.1080/23311975.2021.1935189

[7] Rahman, S., Johari, N. A., Manaff, M. I. A., Mohamad, W. S. S. W., Ramli, R. R., "From good and service tax (GST) to sales and service tax (SST)," Gading Journal for Social Sciences (e-ISSN 2600-7568), vol. 22, no.00, pp.176-181, 2019. https://gadingss.learningdistance.org

[8] Saidi, S., Harun, M., “Goods and Services Tax (GST) transition to Sales and Services Tax (SST): Impact on the welfare of B40 and M40 Households in Malaysia," In Charting a Sustainable Future of ASEAN in Business and Social Sciences, pp. 545-554, 2020.Springer,Singapore. https://doi.org/10.1007/978-981-15-3859-9_47

[9] Lim, K. H., Ooi, P. Q., "Implementing Goods and Services Tax in Malaysia. pp.1-51, 2013.Retrieved from https://penanginstitute.org/gst/GoodsServicesTax_201310 08.pdf 
[10] Mansor, N.H.A., Ilias, A., “Goods and Services Tax (GST): a new tax reform in Malaysia," International Journal of Economics Business and Management Studies, vol.2, no.1, pp.12-19, (2013). https://d1wqtxts1xzle7.cloudfront.net/

[11] Rahman, A. R. A., Ibrahim, N. A., Basar, S. A., “The Effect of Capital Structure on the Performance of Malaysian PLCs during a Transition from SST to GST," Advanced International Journal of Banking, Accounting, and Finance, vol. 3, no.6, pp.69-81, 2021. Doi: 10.35631/AIJBAF.36007

[12] Ghani, E. K., Mohammad, N., Muhammad, K., "Custom Officers' Readiness for Sales and Service Tax Implementation in Malaysia,” An Organisational Readiness for Change, 2021.

[13] Saidi, S., Harun, M., "Goods and Services Tax (GST) transition to Sales and Services Tax (SST): Impact on Household Welfare of B40 and M40 in Malaysia," International Conference on the Future of the Asean (2019). https://www.researchgate.net/profile/

[14] Syeddin, S.N., Hassan, A., Utit, C., Saasri, M.Y., Adb Ghani, J., "Measuring the impacts of Goods and Services Tax (GST) and Sales and Services Tax (SST) on the cost of production in Malaysia: An Input-Output Price Models analysis,” Journal of Business and Social Development, vol. 9, no.1, pp.1-12, 2021. http://doi.org/10.46754/jbsd.2021.0 3.001

[15] Beard, D. W., Dess, G. G., "Industry Profitability and Firm Performance: A Preliminary Analysis on the Business Portfolio Question,” In Academy of Management Proceedings (vol. 1979, no. 1, pp. 123-127). Briarcliff Manor, NY 10510: Academy of Management, (1979, August). https://doi.org/10.5465/ambpp.1979.4975919

[16] Niresh, A., Thirunavukkarasu, V., "Firm size and profitability: A study of listed manufacturing firms in Sri Lanka," International Journal of Business and Management, vol.9, no.4, 2014. Available at SSRN: https://ssrn.com/abst ract $=2422441$

[17] Sudiyatno, B., Puspitasari, E., Kartika, A., "The company's policy, firm performance, and firm Value: An empirical research on Indonesia Stock Exchange," American International Journal of Contemporary Research, vol.2, no.12, pp.30-40, 2012. http://aijcrnet.com/journals

[18] Subramanyam, K. R., "Financial Statement Analysis,” 11th ed., New York: McGraw-Hill Irwin, 2014

[19] Chandren, S., Ahmad, A. C., Mohd Ariff, A. H., Nadarajan, S., "The impact of corporate governance on operating performance during goods \& services tax implementation in
Malaysia,” International Journal of Supply Chain Management (IJSCM), vol.8, no.3, pp.633-643, 2019. https://core.ac.uk

[20] Mironov, M., “Taxes, theft, and firm performance,” The Journal of Finance, vol. 68, no.4, pp.1441-1472, 2013. https://www.jstor.org/stable/42002628

[21] Tsai, C. F., "Feature selection in bankruptcy prediction," Knowledge-Based Systems, vol.22, no.2, pp.120-127, 2009. https://doi.org/10.1016/j.knosys.2008.08.002

[22] Gibson, C. H., “Financial Statement Analysis,”Internationa l Edition, 2013.

[23] Ittelson, T., "Financial statements, revised and expanded 3rd edition: A step-by-step guide to understanding and creating financial reports” Red Wheel/Weiser, 2020.

[24] Davidson, W., "Financial Statement Analysis: Basis for Management Advice,” Association of International Certified Professional Accountants, 2019.

[25] Sanjeeb Kumar Dey, "Impact of Goods and Services Tax on Indirect Tax Revenue of India: With Special Reference to Odisha State," Universal Journal of Accounting and Finance, Vol. 9, No. 3, pp. 431 - 441, 2021. DOI: 10.13189/ujaf.2021.090318

[26] Dao, N. T. T., "Cash Holdings and Over-Investments during Covid 19 Pandemic: The Evidence from Vietnam," Universal Journal of Accounting and Finance, vol.9, no.6, pp.1273-1279, 2021. Doi: 10.13189/ujaf.2021.090607

[27] Andries, P., Faems, D., "Patenting activities and firm performance: does firm size matter?”. Journal of Product Innovation Management, vol.30, no.6, pp.1089-1098, 2013. https://doi.org/10.1111/jpim.12047

[28] Farooq, M., Noor, A., Ali, S., "Corporate governance and firm performance: empirical evidence from Pakistan," Corporate Governance: The International Journal of Business in Society, 2021. https://doi.org/10.1108/CG-072020-0286

[29] Haji, A. A., "The relationship between corporate governance attributes and firm performance before and after the revised code: Some Malaysian evidence," International Journal of Commerce and Management, vol. 24, no.2, pp.134-151, 2014. Doi: 10.1108/IJCoMA-02-201 2-0009

[30] Pagaddut, J.G., "The financial factors affecting the financial performance of Philippine MSMEs," Universal Journal of Accounting and Finance, vol. 9, no.6, pp.1524-1532, 2021. Doi: 10.13189/ujaf.2021.090629 